\title{
Understanding the Level of Self-Directed Learning and Decision-Making Style of Construction-Related Workers
}

\author{
https://doi.org/10.3991/ijim.v13i07.10749 \\ Norhazren Izatie Mohd ${ }^{(凶)}$, Kherun Nita Ali, Shirin Shafiei Ebrahimi and \\ Ahmad Faiz Azizi Ahmad Fauzi \\ Universiti Teknologi Malaysia, Johor Bahru, Malaysia \\ norhazren@utm.my
}

\begin{abstract}
Current serious game framework still lacks in fulfilling the user's requirements. This is due to the framework elements which only focus on the process of delivery. Hence, this study was carried out to determine user's ability in self-directed learning and their styles in making a decision. This study forms part of a larger research on a framework for serious game frameworks for hazard identification training modules. A set of questionnaire consisting of three sections which are demographic, decision-making styles and levels of selfdirected learning was designed. In decision-making styles, 49 items are measured representing eight styles in decision making such as vigilant, dependent, avoidant, anxious, confident, spontaneous, brooding and intuitive. Meanwhile, a self-rating scale consisting of 50 items was used to measure the level of selfdirected learning such as awareness, learning strategies, learning activities, evaluation and interpersonal skills. Data was collected from 319 constructionrelated workers and analysed using mean comparison and ANOVA. Findings confirmed that their style of decision-making is inclined to 'vigilant' and 'brooding' types. The results revealed two levels of self-directed learning, namely, the moderate level for supervisor and high level for general workers, skilled workers, consultants, management teams and safety trainees. This level of self-directed learning is influenced by their level of education and working experiences. The findings also highlight that decision-making style has a moderate relationship with the level of self-directed learning among constructionrelated workers. The study contributes to the understanding of the construction workers' needs in enhancing their skills in becoming independent and lifelong learners
\end{abstract}

Keywords-Decision-making style; Self-directed learning; Constructionrelated worker; Adult learning

\section{$1 \quad$ Introduction}

Nowadays, training using application from technology has become a trend. As a result, some researchers have explored other methods to improve the delivery of training modules especially in terms of the usefulness of technology in creating interactive training [1], [2]. By using technology, training has become more flexible in 
terms of time management, cost and experience [2]. Thus, this study was made to assess the decision-making style and the ability to learn by themselves so as to ensure the serious game training module can be practiced in the industry. This study will be further extended to develop an interactive training module. In sum, the results of this study will not only contribute to a better understanding of construction workers' needs in the area of continuous learning but the findings are also expected to have significant implications on the Malaysian construction industry at large.

\section{$2 \quad$ Literature Reviews}

Adult learner as individuals which be able to take his/her own responsibility regard-ing their life matter (Illeris 2007; p.16). One of the characteristics of the adult learner is self-directed, self- direction or "self-directed learning"; which is the second "pillar" to the field of adult learning and education [4]. Self-direction can be described as a process which learners take initiative by their own self to fulfil their learning needs to achieve their goals [5]. However, in order to train adult learner in making decision, their decision-making styles need to be identified. Hence for the purpose of the study, two main elements which are level of self-directed learning and decisionmaking styles were determined.

\subsection{Self-directed learning}

Self-directed learning can be summarised as a process which learners take their own initiative to achieve their goals especially to improve their ability in the working environment. According to Brookfield (1995) the individual which enjoyed selfdirected learning have high qualities in moral, emotional and intellectual autonomy. He further asserted that individual who are ready to learn by themselves is a contextfree person. This individual already mastered technical skills and consists of three major components which have the ability to identify learning purposes, locate learning resources and manage learning endeavors (p. 155). However, many researchers try to address these characteristics of the self-directed learner Cazan \& Schiopca (2014), Mayhew (2008); Abdullah (2001) have reviewed the literature resulted in a slightly different set of characteristics of self-directed learning which are [1] demon-strate a heighten sense of awareness of their responsibilities in their learning; [2] moti-vation and willingness that drives the decision to participate; [3] learners exercise independence; and [4] the ability to transfer knowledge to new situations. However, the characteristics identified by Abdullah (2001) are congruent with the characteris-tics by Garrison (1997). Garrison (1997) identified characteristics which are self-management, self-monitoring, and motivational dimensions as the foundation for his comprehensive self-directed learning model. Based on the characteristic, he indicates that adult learners become involved in self-directed learning because of their ability to control when, where and the type of learning that takes place. In addition, self-directed learning requires increased levels of effort, focus, direction, motivation, self-control and readiness [11]. 


\subsection{Decision-making style}

The efficiency of decision-making styles lies in telling us something about the deci-sion-maker. Scott \& Bruce (1995) in their study sought to understand how people differ in arriving at a choice, how satisfied people are with their choice Crossley \& Highhouse (2005), and how people arrive at good decisions [14]. Understanding how people arrive at good decisions would provide guidelines to help us eliminate potential errors in judgment. The decision-making style is considered to be a habitual response pattern, which is influenced by characteristics of both the individual and the situation [12]. As such, it appears that, although people generally use one style most of the time based on their individual characteristics, this may vary as required by the situa-tion. Various researchers have classified decision-making style in different perspec-tives. Harren (1979) in this work indicates that there are three decision-making styles in choosing carrier i.e. [1] dependent, [2] rational, and [3] intuitive. Followed by Scott \& Bruce (1995) which has extended the decision-making style categories by added two more styles which are avoidant and spontaneous decision making. Mann et al. (1998) in his study add five subscales which are self-esteem, vigilance, defensive, avoidance, and hyper vigilance. The latest study carried out by Leykin \& DeRubeis (2010) developed The Decision-Making Style Questionnaire which consisted of nine styles, they added five more types of styles which are respected, confident, dependent, brooding and anxious.

\section{$3 \quad$ Methodology}

This study sought to determine the construction-related worker's ability to learn by themselves and style in making decision. Hence, the inferential research approach is applied. This type of research study is associated with describing the characteristics of a specific individual, group or phenomenon. Inferential research process most common procedures involving developing research objectives, collecting data, and making statements about a population based on sample analyses [17]. Thus, in this phase, each variable is solely discussed on determining the level of self-directed learn-ing and style in making decision. This characteristic is determined to understand the ability of the construction-related workers to self-directness. It is also to understand their willingness to learn by themselves to ensure the practicability of serious game training module in Malaysia construction industry.

A questionnaire is an instrument used to determine the level of self-directed learning and decision-making styles among construction-related workers. The purpose of this data collection is to understand construction-related workers capability in making decision and self-directness learning. Therefore, the questionnaire was designed to discover the level of self-directed learning (SDL) and type of decision-making style (DM) in establishing the user characteristics for the serious game training module. The questionnaire is divided into three sections [a] Demographic detail, [b] Decisionmaking style and [c] Level of Self-directed learning. Data were then analysed using compare means methods. Spearman correlation test also conducted to determine 
whether there is or not the relationship between decision-making styles with a level of self-self-directed learning.

\section{$4 \quad$ Results}

Table 1 shows the mean comparison between the construction-related worker's groups. The result shows that the highest mean for General workers and the Semiskilled workers is brooding style $(\mathrm{M}=17.69)$. Thus, it reflects that they are always worrying when they have to make a decision. Meanwhile, the highest value for Skilled workers $(M=17.61)$, Supervisor $(M=19.00)$, Consultant $(M=20.74)$, the Management team $(M=20.22)$ and Trainee $(M=19.58)$ falls into vigilant style. The vigilant style means they are being too careful when making a decision. They considered the pros and cons before making a decision. General workers and Semi-skilled workers are the only groups which is categorised under brooding style for making a decision. These findings gave new perspectives towards these groups because the brooding style is described as a serious thinker who is always worrying when they need to make a decision. The brooding style is also known as a serious type which realistically is aware of their own capabilities. Serious people are responsible for their actions, but in the decision-making, they always worry when they need to make a decision. Hence, this finding is surprisingly different from their role on the site. Both groups are following the orders from the top management on the construction site, they do not require to make a major decision and have a limited scope of work. However, both groups are the riskiest groups that always are involved in accidents on the construction sites. Hence, all these findings will become guidance in designing the flow and level for serious game training framework.

Table 1. Compare means for decision-making styles

\begin{tabular}{|l|c|c|c|c|c|c|}
\hline & $\begin{array}{c}\text { General \& } \\
\text { Semi-skilled } \\
\text { workers }\end{array}$ & $\begin{array}{c}\text { Skilled work- } \\
\text { ers }\end{array}$ & Supervisor & Consultant & $\begin{array}{c}\text { Management } \\
\text { team }\end{array}$ & $\begin{array}{c}\text { Safety } \\
\text { trainees }\end{array}$ \\
\hline Avoidant & 15.48 & 14.61 & 13.83 & 14.09 & 13.17 & 15.01 \\
\hline Dependent & 17.24 & 15.96 & 16.81 & 16.13 & 16.54 & 18.44 \\
\hline Confident & 16.59 & 16.65 & 16.77 & 16.13 & 16.17 & 17.16 \\
\hline Anxious & 16.59 & 16.04 & 15.13 & 16.00 & 13.29 & 16.51 \\
\hline Vigilant & 17.66 & 17.61 & 19.00 & 20.74 & 20.22 & 19.58 \\
\hline Spontaneous & 17.14 & 16.39 & 15.98 & 16.78 & 15.43 & 16.58 \\
\hline Intuitive & 13.93 & 13.74 & 11.98 & 13.48 & 12.24 & 13.72 \\
\hline Brooding & 17.69 & 16.61 & 16.50 & 16.13 & 16.03 & 17.34 \\
\hline
\end{tabular}

Descriptive statistics with a mean score between the group of construction-related workers and level of self-directed learning are shown in Table 2. The results show the respondents' level of self-directed learning based on five broad areas. For awareness, the area is measured according to the ability of the respondent to understand the factors that contribute to becoming self-directed learning, for example, internal motivation, self-motivation, and decision-making. Results show that all groups of workers 
like General workers and Semi-skilled workers $(M=37.28)$, Consultant $(M=40.26)$, the Management team $(M=38.83)$, Supervisor $(M=36.98)$, and Safety trainee $(\mathrm{M}=38.48)]$ except for Skilled-workers $(\mathrm{M}=35.09)$ group have a high level of awareness in self-directed learning. It is relatively easy to describe that respondents are aware of the importance of continuous learning and always attend various training to enhance their learning according to the needs of the industry. All respondents were able to identify their learning needs, keep up-to-date with available educational resources and have a high level of self-motivation. Furthermore, the respondents believe that they have the ability to plan and select the learning methods for themselves. Thus, it can be concluded that construction-related workers have a high level of awareness and responsibility in anticipating a lifelong learning process.

Table 2. Compare means for the level of self-directed learning

\begin{tabular}{|c|c|c|c|c|c|c|}
\hline \multirow{2}{*}{$\begin{array}{l}\text { Group of } \\
\text { Workers }\end{array}$} & \multirow[b]{2}{*}{$\mathbf{N}$} & \multicolumn{5}{|c|}{ Mean } \\
\hline & & Awareness & $\begin{array}{l}\text { Learning } \\
\text { Strategy }\end{array}$ & $\begin{array}{l}\text { Learning } \\
\text { Activities }\end{array}$ & Evaluation & $\begin{array}{l}\text { Interpersonal } \\
\text { skills }\end{array}$ \\
\hline $\begin{array}{l}\text { General \& Semi- } \\
\text { skilled workers }\end{array}$ & 29 & 37.28 & 37.66 & 36.62 & 37.52 & 38.83 \\
\hline Skilled workers & 23 & 35.09 & 36.83 & 36.52 & 36.52 & 37.30 \\
\hline Supervisor & 48 & 36.98 & 37.10 & 37.71 & 38.63 & 38.17 \\
\hline Consultant & 23 & 40.26 & 39.78 & 39.35 & 40.57 & 41.65 \\
\hline $\begin{array}{l}\text { Management } \\
\text { team }\end{array}$ & 63 & 38.83 & 38.56 & 38.52 & 38.71 & 39.00 \\
\hline Safety trainees & 133 & 38.48 & 39.02 & 38.75 & 39.14 & 39.74 \\
\hline TOTAL : & 319 & 38.10 & 38.41 & 38.24 & 38.75 & 39.24 \\
\hline
\end{tabular}

Learning strategy is the second area of self-directed learning that needs to be measured. This area would determine the ability of construction-related workers in adopting various strategies in their learning process. Group discussion, 'role plays' learning, case study, and learning aid with technology are the examples of learning strategy that could apply to self-directed learning. The results show all group of workers have a high level of learning strategy. Consultant group are the highest scorers $(M=39.78)$, followed by the rest. The next area is related to the required learning activities that construction-related workers should actively engage to become selfdirected in their learning process. For this area, all groups of workers have a high level of the mean scores which is above 36.00. Consultant $(M=39.35)$ had the highest mean scores, followed by Safety trainees group $(M=38.75)$, the Management team $(M=38.52)$, Supervisor $(M=37.71)$, General workers and Semi-Skilled workers $(M=36.62)$ and Skilled workers $(M=36.52)$. Based on the results, it can be concluded that all construction-related workers have the ability to make notes by using mapping concept, make a summary of learning, be able to use information technology, pose relevant questions in teaching-learning session and related experience with their learning.

In determining the level of self-directed learning, construction-related workers not only participate in their learning but also they need to have specific attributes to help monitor their learning activities. They should be able to make self-assessment, criti- 
cism, review and find a new challenge in learning. For this area, evaluation, the results show that the construction-related workers have a high level to make an evaluation for their study. As expected, the Consultant group is the highest with a mean score of 40.57 , followed by Safety trainees group $(\mathrm{M}=39.14)$, the Management team $(\mathrm{M}=38.71)$, Supervisor $(\mathrm{M}=38.63)$, General workers and Semi-Skilled workers $(\mathrm{M}=37.52)$ and Skilled workers $(\mathrm{M}=36.52)$. The last area of self-directed learning is the interpersonal skills which are related to the Skilled in the interpersonal relationship. This area is a pre-requisite to the construction-related workers in becoming selfdirected learners. Analysis of the data reveals that all groups of workers have a high level of mean scores in this area. Consultant group $(\mathrm{M}=41.65)$ is still in the lead with the highest mean score among the other group of workers. Followed by Safety trainees group $(M=39.74)$, Management team $(M=39.00)$, General workers and Semiskilled workers $(M=38.83)$, Supervisor $(M=38.17)$, and Skilled workers $(M=37.30)$. The construction-related workers especially the Consultant group can interact with others without having any problems. They share information with others and can express their views clearly and also they can make use of any opportunities when it is available.

All mean scores from five broad areas were computed and transformed into a single variable which is self-directed learning. Three levels of self-directed learning (low/dependent, moderate/interest and high/independent) were determined. Finally, it was inferred that Consultant group $(\mathrm{M}=40.32)$ has the highest mean score, followed by Safety trainee group $(M=39.02)$, Management team $(M=38.72)$, Supervisor $(\mathrm{M}=37.71)$, General workers and Semi-skilled workers $(\mathrm{M}=37.57)$, and Skilled workers $(M=36.45)$.

After that, the Spearman rho correlation test was carried out to determine whether there is or not the relationship between decision-making styles with a level of selfself-directed learning among the construction-related workers. This relationship will determine whether the level of self-directed learning influence the decision-making style among construction-related worker. Spearman correlation test analysis results in Table 3 and Figure 1 indicate that the relationship between decision-making styles and level of self-directed learning is significant $(r=.37, \mathrm{p}<.05)$. Thus, it shows that there is a relationship between decision-making styles and level of self-directed learning among the construction-related workers. The strength of the relationship between the decision-making styles and level of self-directed learning is moderate $(\mathrm{r}=.37)$. Based on the results, it can be concluding that the decision-making styles are related to the level of self-directed learning within the population of the construction-related works. 
Table 3. Correlation between self-directed learning and decision-making style

\begin{tabular}{|c|c|c|c|c|}
\hline & & & SDL & TDMS \\
\hline & & Correlation Coefficient & 1.000 & $.373^{* *}$ \\
\hline & Level of Self-directed & Sig. (2-tailed) & & .000 \\
\hline & & $\mathrm{N}$ & 319 & 319 \\
\hline Spearman is rho & & Correlation Coefficient & $.373^{* *}$ & 1.000 \\
\hline & Decision-making Styles & Sig. (2-tailed) & .000 & \\
\hline & & $\mathrm{N}$ & 319 & 319 \\
\hline
\end{tabular}

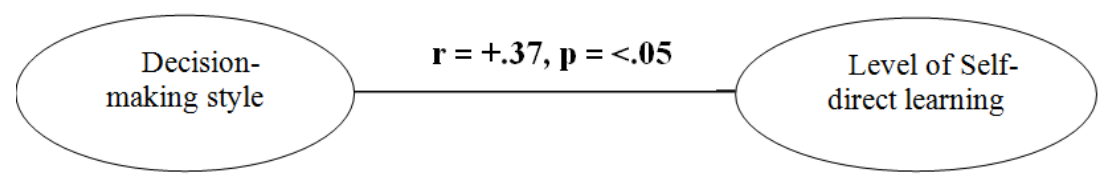

Fig. 1. Correlation between level of self-directed learning and decision-making style

\section{Discussion}

The result of the findings indicates that General workers and Semi-skilled workers fall under brooding styles and the rest are under vigilant styles. It shows that General workers and Semi-skilled workers are not only low profile but always think deeply before making a decision. Usually, they will regret the actions or decisions that they have made. However, they are always responsible for the action they have taken. Meanwhile, for skilled workers, Supervisors, Consultants, Management teams and Safety trainees, they are more vigilant in making a decision. These findings show that they are independent people who have insights and very careful in protecting their own interest. Despite this, they are loyal and always alert to criticism. Both of these styles need to be improved and changed toward spontaneous styles in making a decision. Time is the essence in handling the hazard especially when the unexpected hazard emerges during the working environment.

The construction-related workers need to be able to take immediate action to prevent accident occurrence on the construction site. These findings will guide the designer or trainer to design an appropriate decision-making process to train the construction-related workers to make immediate and wise decision in handling hazard on the construction site. In terms of self-directed learning, all groups of workers have the ability to self-directness. They have the aptitude to take initiative in identifying their learning needs.

Besides, they are capable of formulating their learning goals and choose resources for learning. Moreover, with their expertise, they are able to employ suitable learning strategies and assessing the learning outcome according to their needs. It shows that the construction-related workers have the capability to choose their own needs of learning and learn by themselves. This is where the level of self-directed learning among construction-related workers can bridge the missing link between the needs for knowledge and hands-on training. In evaluating the self-directed learning among 
construction-related workers, this study has identified five broad areas of self-directed learning (i.e. awareness, learning strategies, learning activities, evaluation and Interpersonal skills).

As a summary, in term of making a decision, General workers and Semi-skilled workers are more on serious (brooding style) in making a decision. The rest of the groups are categorised under the vigilant style. For self-directed learning, the construction-related workers are an independent learner who has a high level of selfdirectness. Table 4 below shows the summary of findings of user characteristic for the construction-related workers.

Table 4. Summary of user characteristic

\begin{tabular}{|l|l|l|}
\hline \multicolumn{1}{|c|}{ User character } & $\begin{array}{l}\text { Scope of character in making } \\
\text { decision }\end{array}$ & \multicolumn{1}{c|}{ User character } \\
\hline $\begin{array}{l}\text { General workers and Semi-Skilled } \\
\text { workers (brooding style) }\end{array}$ & $\begin{array}{l}\text { No pretentious - low profile } \\
\text { Accountability - responsible } \\
\text { Cogitation - thinking deeply } \\
\text { Contrition - regret }\end{array}$ & $\begin{array}{l}\text { The learner has the ability in: } \\
\text { taking the initiative in } \\
\text { identifying their learning needs } \\
\text { formulating learning goals } \\
\text { choosing learning } \\
\text { resources } \\
\text { employing suitable } \\
\text { learning strategies } \\
\text { assessing learning } \\
\text { outcomes }\end{array}$ \\
\hline Skilled workers (vigilant style) & $\begin{array}{l}\text { Autonomy - Independent } \\
\text { Caution - careful } \\
\text { Serceptiveness - insightful } \\
\text { Supervisor (vigilant style) }\end{array}$ & $\begin{array}{l}\text { Self-defence - protect own } \\
\text { interest } \\
\text { Alertness to criticism } \\
\text { Fidelity - loyalty }\end{array}$ \\
\hline Consultant (vigilant style) &
\end{tabular}

\section{Conclusion}

It is an anticipated result because the development of game training module would be a great significance in enhancing knowledge. The construction-related workers will be encouraged to keep developing themselves and to keep up with the industry requirements. By adopting serious games as training tools, it will provide a good prospect for the construction industry. The serious game offers an affordable, interactive and entertaining module. It also provides a flexibility training module which can be easily accessed at any time and anywhere according to the needs of the constructionrelated workers.

\section{$7 \quad$ Limitation and Future Study}

In developing the games training modules, there are three elements that should be considered which are the input, process and outcome. All these three elements gave significance in terms of the body of knowledge, especially in training delivery for hazard identification. This is ongoing research which this output will be integrated with other elements to design the serious game framework for the hazard identification training module. 


\section{$8 \quad 8$ Acknowledgement}

The authors would like to acknowledge MyBrain15 for the financial support of the study.

\section{References}

[1] C.-L. Ho and R.-J. Dzeng, "Construction safety training via e-Learning: Learning effectiveness and user satisfaction," Comput. Educ., vol. 55, p. 9, 2010.

[2] H. Xie, M. E. Tudoreanu, and W. Shi, "Development of a Virtual Reality Safety-Training System for Construction Workers," Digit. Libr. Constr. Inf., p. 9, 2006.

[3] K. Illeris, "What is special about adult learning?," in Lifelong Learning concepts and contexts, 2nd ed., P. Sutherland and J. Crowther, Eds. United States, America: Routledge Taylor \& Francis Group London and New York, 2007, pp. 15-23.

[4] S. B. Merriam, R. S. Caffarella, R. J. Wlodkowski, and P. Cranton, "Key Theories of Learning," in Adult Learning - Theories, Principles and Applications, John Wiley \& Sons, Inc., 2001, pp. 76-85.

[5] B. E. Ahmad and F. A. Majid, "Self-directed Learning and Culture: A Study on Malay Adult Learners," Procedia - Soc. Behav. Sci., vol. 7, no. C, pp. 254-263, Jan. 2010. https://doi.org/10.1016/j.sbspro.2010.10.036

[6] S. Brookfield, "Adult Learning : An Overview Major Areas of Research on Adult Learning Self-Directed Learning," Int. Encycl. Educ., pp. 1-11, 1995.

[7] A.-M. Cazan and B.-A. Schiopca, "Self-directed Learning, Personality Traits and Academic Achievement," Procedia - Soc. Behav. Sci., vol. 127, pp. 640-644, 2014. https://doi.org/10.1016/j.sbspro.2014.03.327

[8] J. a. Mayhew, "Adult learners' perceptions of their employers' leadership behaviours and their own readiness for self-directed learning," p. 180, 2008.

[9] M. H. Abdullah, "What are the benefits of Seld-directed," ERIC Clear. Read. English Commun. Bloom. IN., pp. 1-6, 2001.

[10] R. Garrison, "Self-directed learning : Toward a Comprehensive Model," Adult Educ. Q., vol. 48, no. 1, pp. 18-33, 1997.

[11] L. M. Guglielmino, "Why Self-Directed Learning?," Int. J. Self-Directed Learn., vol. 5, no. 1, pp. 1-14, 2008.

[12] S. G. Scott and R. a. Bruce, "Decision-Making Style: The Development and Assessment of a New Measure," Educ. Psychol. Meas., vol. 55, no. 5, pp. 818-831, 1995.

[13] C. D. Crossley and S. Highhouse, "Relation of job search and choice process with subsequent satisfaction," J. Econ. Psychol., vol. 26, no. 2, pp. 255-268, 2005.

[14] Y. Leykin and R. J. DeRubeis, "Decision-making styles and depressive symptomatology: Development of the Decision Styles Questionnaire," Judgm. Decis. Mak., vol. 5, no. 7, pp. 506-515, 2010.

[15] V. A. Harren, "A model of career decision making for college students," J. Vocat. Behav., vol. 14, no. 2, pp. 119-133, 1979.

[16] L. Mann, M. Radford, P. Burnett, S. Ford, M. Bond, K. Leung, H. Nakamura, G. Vaughan, and K.-S. Yang, "Cross-cultural differences in self-reported decision-making style and confidence," Int. J. Psychol., vol. 33, no. 5, pp. 325-335, 1998. https://doi.org/10. $\underline{1080 / 002075998400213}$ 
[17] N. Idris, "Pengenalan kepada Penyelidikan," in Penyelidikan dalam Pendidikan, Selangor: McGraw-Hill (Malaysia) Sdn. Bhd, 2013, pp. 1-16.

\section{Authors}

Norhazren Izatie Mohd is a senior lecturer at Quantity Surveying Department, Faculty of Built Environment, Universiti Teknologi Malaysia. She is a member of Royal Institution Surveyor Malaysia (RISM) and Building Information Modelling Research Group (BIMRG). Her research interests are gamification, destructive technology, construction safety, and adult training.

Kherun Nita Ali is an Associate Professor at the Faculty of Built Environment, Universiti Teknologi Malaysia. She is the Head of Building Information Center for Digital Innovations and Solutions (BIMCDIS), Faculty of Built Environment, Universiti Teknologi Malaysia, Johor Bahru. Having been also the Head of BIM Research Group in UTM, she is currently active in researches and publications related to Building Information Modelling (BIM). Her recent works with her research team are Enhancing Cost Planning and Control through 5D BIM, BIM Deployment Plan for QS Firms, Facilities Management (7D) BIM, Managing Safety through BIM and GIS BIM. Other research works also include 4.0 IR in higher education and Mobile Augmented Reality for teaching and learning Quantity Surveying courses. She is a member of Royal Institutions of Surveyors Malaysia (RISM) BIM Technical Committee since its establishment in 2011.

Shirin Shafiei Ebrahimi is the Postdoctoral Fellow at the Faculty of Education, Universiti Teknologi Malaysia. She is interested in doing research in multidisciplinary areas such as the use of technology in education.

Ahmad Faiz Azizi Ahmad Fauzi is a 2nd Year postgraduate student from Universiti Teknologi Malaysia. He is currently pursuing his MSc in Philosophy under the Department of Quantity Surveying, Faculty of Built Environment and Surveying. Prior to this, he received his Bachelor's degree in Quantity Surveying as well as his Diploma in Quantity surveying from UTM. His primary research interests are in the field of Education Technology, Augmented Reality in Education and Construction related fields.

Article submitted 2019-03-27. Resubmitted 2019-05-04. Final acceptance 2019-06-01. Final version published as submitted by the authors. 